\title{
Pengaruh Kepemimpinan Pembelajaran, Kepemimpinan Perubahan, Kepemimpinan Spiritual, Budaya Sekolah, dan Etika Profesi terhadap Kinerja Mengajar Guru
}

\author{
Desi Eri Kusumaningrum, Raden Bambang Sumarsono, Imam Gunawan \\ Jurusan Administrasi Pendidikan Fakultas Ilmu Pendidikan Universitas Negeri Malang \\ Jalan Semarang 5 Malang 65145 \\ desi.eri.fip@um.ac.id
}

Article received: January 2020; revised : February 2020 ; accepted : July 2020

DOI : 10.17977/um025v4i32020p198

\begin{abstract}
Empowerment of Human Resources (HR) is directed to increase HR participation in organizations and increase productivity. The results of various studies show that HR is a determinant of productivity. HR in the field of education can be grouped into three groups, namely the principal, teachers, and TAS. School competitiveness is also determined by the human resources it has. This research was conducted in a pesantren-based Junior High School (SMP) in East Java. The schools which are the research sites are: (1) SMP Insan Terpadu Probolinggo; (2) SMP Assa'adah Gresik; dan (3) SMP An Nur Bululawang Malang. This research refers to the Model of Empowerment of Islamic Boarding School-Based Human Resources Empowerment with Soft System Methodology Approach that has been designed. Researchers take quantitative measurements of the variables that impact the existence of the model. The variables measured were six variables, namely: learning leadership, change leadership, spiritual leadership, school culture, professional ethics, and teacher teaching performance. The method to be used is quantitative research. Measurement of the six variables is using a questionnaire instrument. The analysis that will be used is descriptive and regression analysis. Based on the results of data analysis, it can be concluded that there is a significant influence of learning leadership, change leadership, spiritual leadership, school culture, and professional ethics on the teaching performance of pesantren-based junior high schools in East Java.
\end{abstract}

Keywords: empowerment; human resources; boarding school-based; soft system methodology; instructional leadership; change leadership; spiritual leadership; school culture; professional ethics; teacher teaching performance

\begin{abstract}
Abstrak: Pemberdayaan sumber daya manusia (SDM) diarahkan untuk meningkatkan partisipasi SDM dalam organisasi dan meningkatkan produktivitas. Hasil berbagai studi menunjukkan bahwa SDM merupakan faktor penentu produktivitas. SDM bidang pendidikan tataran sekolah dapat dikelompokkan menjadi tiga, yaitu kepala sekolah, guru, dan TAS. Daya saing sekolah juga ditentukan oleh SDM yang dimiliki. Penelitian ini dilaksanakan di SMP berbasis pesantren di Jawa Timur. Sekolah yang menjadi tempat penelitian ialah: (1) SMP Insan Terpadu Probolinggo; (2) SMPAssa'adah Gresik; dan (3) SMPAn Nur Bululawang Malang. Penelitian ini mengacu pada rancangan Model Pemberdayaan Sumber Daya Manusia Sekolah Menengah Pertama Berbasis Pesantren dengan Pendekatan Soft System Methodology. Peneliti melakukan pengukuran secara kuantitatif terhadap variabel yang menjadi dampak adanya model tersebut. Adapun variabel yang diukur ada enam variabel, yaitu: kepemimpinan pembelajaran, kepemimpinan perubahan, kepemimpinan spiritual, budaya sekolah, etika profesi, dan kinerja mengajar guru. Metode yang akan digunakan adalah penelitian kuantitatif. Pengukuran terhadap keenam variabel tersebut adalah dengan instrumen angket. Analisis yang akan digunakan adalah analisis deskriptif dan regresi. Berdasarkan hasil analisis data dapat disimpulkan ada pengaruh yang signifikan kepemimpinan pembelajaran, kepemimpinan perubahan, kepemimpinan spiritual, budaya sekolah, dan etika profesi terhadap kinerja mengajar guru Sekolah Menengah Pertama (SMP) berbasis pesantren di Jawa Timur.
\end{abstract}

Kata Kunci: pemberdayaan; sumber daya manusia; sekolah berbasis pesantren; soft system methodology; kepemimpinan pembelajaran; kepemimpinan perubahan; kepemimpinan spiritual; budaya sekolah; etika profesi; kinerja mengajar guru 
Aktivitas utama yang dilaksanakan sekolah adalah kegiatan pembelajaran. Kepemimpinan pembelajaran menjadi model kepemimpinan yang penting untuk diterapkan oleh kepala sekolah. Kepemimpinan pembelajaran adalah tindakan yang dilakukan dengan maksud mengembangkan lingkungan kerja yang produktif dan memuaskan bagi guru, serta pada akhirya mampu menciptakan kondisi belajar siswa meningkat (Eggen \& Kauchak, 2014; Gunawan, dkk., 2019a). Kepemimpinan pembelajaran sebagai upaya memimpin para guru agar mengajar lebih baik, yang pada gilirannya dapat memperbaiki prestasi belajar siswanya (Daresh \& Playco, 1995). Kepala sekolah memberikan dukungan terhadap pembelajaran, misalnya kepala sekolah mendukung bahwa pengajaran yang memfokuskan pada kepentingan belajar siswa harus menjadi prioritas (Patterson, 1993).

Kepala sekolah melakukan pemantauan terhadap proses belajar mengajar, sehingga memahami lebih mendalam dan menyadari apa yang sedang berlangsung di dalam sekolah. Keberhasilan kepala sekolah efektif sebagai pemimpin pembelajaran adalah: (1) sebagai penyedia sumber daya, yakni mampu mengelola waktu, kondisi kelas, dan memotivasi guru; (2) sebagai sumber instruksional, yakni memajukan kondisi kelas yang efektif untuk menunjang hasil belajar; (3) sebagai komunikator, yakni mampu menyampaikan visi dan memahami tujuan sekolah kepada guru; dan (4) kehadirannya bermakna, yakni mampu berinteraksi dan mempengaruhi seluruh warga sekolah (Jenkins, 2009; Nurabadi, dkk., 2019a). Kepemimpinan kepala sekolah menjadi faktor penting dalam meningkatkan mutu pendidikan sekolah.

Sekolah sebagai organisasi pendidikan juga akan menghadapi perubahan. Perubahan mencakup perubahan dalam manusia, struktur, atau teknologi (Robbins \& Coulter, 2015). Perubahan yang dihadapi organisasi mencakup perubahan dalam unsur lingkungan, nilai, dan sumber daya. Kepemimpinan perubahan dapat meningkatkan refleksi tim terhadap hasil kinerjanya dan fokus terhadap upaya mengoreksi kesalahan serta upaya mengembangkan organisasi (Kalmanovich-Cohen, dkk., 2018; Gunawan, dkk., 2018a). Kepemimpinan perubahan adalah perilaku kepala sekolah sebagai seorang pemimpin yang lebih difokuskan pada menggerakkan pendidikan dan tenaga kependidikan dalam melakukan perubahan yang tiada henti untuk meningkatkan kualitas pembelajaran.

Taylor, dkk., (2011) menyatakan kepala sekolah yang profesional dan menerapkan kepemimpinan perubahan mempengaruhi secara signifikan kinerja mengajar guru. Wills (2016) berdasarkan hasil penelitiannya menyimpulkan kepemimpinan perubahan memiliki pengaruh secara langsung terhadap kinerja sekolah dan kinerja mengajar guru. Katkat (2014) menyatakan bahwa kapasitas kepemimpinan perubahan akan menentukan level kinerja para bawahannya. Sesuai dengan pendapat Katkat (2014) maka kapasitas kepemimpinan perubahan kepala sekolah juga menentukan kinerja guru. Leavitt (2016) mengemukakan bahwa dalam rangka melaksanakan perubahan organisasi ada empat macam strategi yang dapat dipilih, yaitu: (1) perubahan struktur organisasi; (2) perubahan teknologi; (3) perubahan tugas; dan (4) perubahan manusianya. Serangkaian tindakan kepala sekolah sebagai pemimpin perubahan dalam wujud: (1) menatap masa depan dan merancang perubahan guna mengantisipasi masa depan (visioner); (2) menginspirasi para guru untuk menatap masa depan agar melakukan perubahan; (3) menetapkan langkah strategis perubahan; (4) pelaksanaan perubahan; dan (5) mengevaluasi perubahan dan merencanakan tindak lanjut (Bafadal, dkk., 2016; Kusumaningrum, dkk., 2017a; Bafadal, dkk., 2019).

Spiritualitas kepemimpinan sebagai penggabungan nilai, sikap, dan perilaku yang diperlukan untuk memotivasi diri dan orang lain secara intrinsik, sehingga mereka memiliki kepemimpinan spiritual sebagai panggilan tugas (Frey, 2003; Gunawan, dkk., 2018b). Kepemimpinan spiritual bertujuan untuk memotivasi dan menginspirasi para staf melalui penciptaan visi dan budaya yang didasarkan pada nilai-nilai altruistik untuk menghasilkan para tenaga kerja yang memiliki komitmen organisasi dan produktivitas (Fry, dkk., 2005; Gunawan, dkk., 2019b). Nilai spiritual yang bisa dilakukan kepala sekolah yaitu kejujuran, kedisiplinan, dan tanggung jawab. Nilai-nilai spiritualitas akan berdampak pada semangat kerja para SDM di sekolah. 
Kepemimpinan spiritual dioperasionalisasikan Bafadal, dkk., (2018a) menjadi serangkaian tindakan kepala sekolah dalam bentuk: (1) kerja keras yang didasari dengan tanggung jawab (2) kedisiplinan; (3) kejujuran; (4) keteladanan; dan (5) selalu bersyukur dalam setiap meraih keberhasilan dan kegagalan yang didasari dengan keikhlasan dan kesabaran. Polat (2011) menyatakan kepemimpinan spiritual memiliki pengaruh yang signifikan terhadap kinerja bawahan Kepemimpinan spiritual mempengaruhi penilaian bawahan terhadap gaya kepemimpinan dan dapat meningkatkan kinerja bawahan (Yi-Chen \& Li, 2013). Kepemimpinan spiritual akan lebih bermakna manakala diiringi dengan nilai dan sikap yang bersumber dari kearifan-kearifan yang universal (Whittington, dkk., 2005; Nurabadi, dkk., 2019b).

Budaya sekolah digunakan sebagai pedoman semua warga sekolah bagaimana seyogyanya bersikap terhadap profesinya dan mampu melakukan adaptasi terhadap rekan kerja serta lingkungan kerjanya. Sehingga akan terbentuk suatu sistem nilai, kebiasaan, etos kerja, dan citra sekolah yang terinternalisasi dalam setiap sendi aktivitas warga sekolah. Penting bagi guru untuk membangun definisi operasional tentang budaya sekolah yang membuat eksplisit-sentralitas dan sifat sistemiknya dalam realitas eksistensi sumber daya manusia di sekolah (Hollins, 2008). Budaya organisasi merupakan sekumpulan pengalaman, nilai-nilai, dan norma-norma yang diyakini oleh organisasi. Keyakinan tersebut menjadi spirit semua staf melakukan aktivitas bekerja. Oleh sebab itu, budaya organisasi merupakan seperangkat asumsi organisasi yang berkembang melalui proses belajar dari penyesuaian terhadap tantangan eksternal dan internal organisasi. Budaya sekolah yang baik akan mendorong pimpinan sekolah memberikan apresiasi terhadap setiap peningkatan prestasi kerja para bawahannya.

Etika dapat diartikan sebagai kumpulan nilai, asas, atau moral yang menjadi pedoman seseorang dan/atau kelompok orang dalam berperilaku (Sultoni, dkk., 2018c). Etika profesi ditunjukkan dengan: (1) adanya kesadaran individu terhadap aturan dan nilai yang telah berlaku serta telah disepakati; (2) adanya kesediaan individu melakukan dialog dengan entitas organisasi; dan (3) etika dijadikan pedoman melakukan interaksi antara semua anggota organisasi (Greenstone, 2018). Guru sebagai profesi juga memiliki etika profesi yang harus menjadi pedoman semua guru.

Etika tersebut bersifat mengikat secara sosial, moral, dan hukum, sebab etika guru tersebut menjadi acuan guru dalam berperilaku dalam lingkungan pendidikan dan di luar lingkungan pendidikan. Oleh sebab itu, etika guru dapat dikatakan mengikat. Etika profesi akan mengalami dinamika seiring dengan dengan perkembangan dan tuntutan pada jamannya (Sultoni, dkk., 2018c). Guru sebagai profesi mulia dituntut untuk mampu beradaptasi dengan perubahan jaman, tanpa mengesampingkan nilai-nilai dan etika luhur. Guru selain profesi, juga dianggap masyarakat umum sebagai teladan bagi kehidupan masyarakat.

Kinerja mengajar guru adalah kualitas guru dalam melaksanakan tugas-tugas utamanya, yaitu kualitas dalam menyelenggarakan pendidikan dan pembelajaran. Program yang dapat meningkatkan kinerja guru dalam mengajar yakni dengan pengelolaan manajemen kelas dan penilaian pembelajaran secara kontinu (Bruns, dkk., 2018; Kusumaningrum, dkk., 2018a). Serangkaian kinerja guru dalam pembelajaran adalah: (1) menyusun perencanaan pembelajaran; (2) melaksanaan pembelajaran; (3) mengevaluasi proses dan hasil pembelajaran; dan (4) menyelenggarakan program tindak lanjut pembelajaran.

Kinerja guru tidak timbul secara otomatis, melainkan perlu diidentifikasi, difasilitasi, dan dikembangkan serta dipelihara demi mencapai tujuan sekolah. Oleh sebab itu, kepala sekolah sebagai pimpinan tertinggi di institusi sekolah, perlu mengetahui faktor-faktor penentu kinerja agar mampu mendorong bahkan melejitkan kinerja mereka secara maksimal. Kinerja mengajar guru dioperasionalisasikan Bafadal, dkk., (2018b) menjadi serangkaian kegiatan guru dalam: (1) menyusun perencanaan pembelajaran; (2) melaksanaan pembelajaran; (3) mengevaluasi proses dan hasil pembelajaran; dan (4) menyelenggarakan program tindak lanjut pembelajaran. Tujuan penelitian ini adalah untuk mengetahui apakah ada pengaruh yang signifikan kepemimpinan pembelajaran, kepemimpinan perubahan, kepemimpinan spiritual, budaya sekolah, dan etika profesi terhadap kinerja mengajar guru. 


\section{METODE}

Penelitian ini merupakan penelitian Tahun III DRPM Kemristekdikti tahun 2019. Penelitian ini dilaksanakan di SMP berbasis pesantren di Jawa Timur. Sekolah yang menjadi tempat penelitian ialah: (1) SMP Insan Terpadu Probolinggo; (2) SMP Assa'adah Gresik; dan (3) SMP An Nur Bululawang Malang. Penelitian ini menguji variabel sebagai dampak implementasi Model Pemberdayaan Sumber Daya Manusia Sekolah Menengah Pertama Berbasis Pesantren dengan Pendekatan Soft System Methodology (Kusumaningrum, dkk., 2017b; Kusumaningrum, dkk., 2018b; Kusumaningrum, dkk., 2019), terhadap enam variabel, yaitu: kepemimpinan pembelajaran, kepemimpinan perubahan, kepemimpinan spiritual, budaya sekolah, etika profesi, dan kinerja mengajar guru. Berdasarkan tujuan penelitian, penelitian Tahun III 2019 ini dilaksanakan dengan pendekatan penelitian kuantitatif.

Pengukuran terhadap keenam variabel tersebut adalah dengan instrumen angket. Analisis yang digunakan adalah analisis deskriptif dan analisis regresi (Cresswell, 2009; Gunawan, 2014; Gunawan, 2017). Analisis deskriptif dengan menghitung mean, median, mode, deviasi standar, range, skor minimum, dan skor maximum. Hasil analisis deskriptif selanjutnya disajikan dalam bentuk tabel. Sebelum data dianalisis regresi, data diuji asumsi, yang meliputi normalitas, homogenitas, dan linieritas. Analisis regresi bertujuan untuk mencari persamaan regresi variabel prediktor dan kriterium. Analisis data penelitian menggunakan bantuan program IBM SPSS Statistics 20.

\section{HASIL DAN PEMBAHASAN}

\section{Deskripsi Data}

Berdasarkan rancangan penelitian, berikut ini disajikan hasil pengukuran variabel dari dampak adanya penerapan model pemberdayaan sumber daya manusia sekolah menengah pertama berbasis pesantren dengan pendekatan soft system methodology. Hasil pengukuran ini mencakup enam variabel, yaitu: kepemimpinan pembelajaran, kepemimpinan perubahan, kepemimpinan spiritual, budaya sekolah, etika profesi, dan kinerja mengajar guru. Berikut ini disajikan hasil pengukuran keenam variabel tersebut.

\section{Deskripsi Data SMP An Nur Bululawang Malang}

Berdasarkan hasil deskripsi data variabel kepemimpinan pembelajaran (X1) diketahui: rerata 62,58; deviasi standar 5,64; skor maksimum 71; skor minimum 49; range 22; dan interval 6. Adapun deskripsi frekuensi variabel kepemimpinan pembelajaran (X1) disajikan pada Tabel 1.

Tabel 1 Distribusi Frekuensi Variabel Kepemimpinan Pembelajaran (X1)

\begin{tabular}{|c|c|c|c|}
\hline Kategori & Interval & f & $\%$ \\
\hline Sangat rendah & $49-54$ & 3 & 9,68 \\
\hline Rendah & $55-60$ & 5 & 16,13 \\
\hline Cukup & $61-66$ & 16 & 51,61 \\
\hline Tinggi & $67-72$ & 7 & 22,58 \\
\hline Sangat tinggi & $73-78$ & 0 & 0,00 \\
\hline
\end{tabular}

Berdasarkan hasil deskripsi data variabel kepemimpinan perubahan (X2) diketahui: rerata 52,52; deviasi standar 5,77; skor maksimum 64; skor minimum 39; range 25; dan interval 6 . Adapun deskripsi frekuensi variabel kepemimpinan perubahan (X2) disajikan pada Tabel 2. 
Tabel 2 Distribusi Frekuensi Variabel Kepemimpinan Perubahan (X2)

\begin{tabular}{|c|c|c|c|}
\hline Kategori & Interval & f & $\%$ \\
\hline Sangat rendah & $39-44$ & 2 & 6,45 \\
\hline Rendah & $45-50$ & 10 & 32,26 \\
\hline Cukup & $51-56$ & 11 & 35,48 \\
\hline Tinggi & $57-62$ & 6 & 19,35 \\
\hline Sangat tinggi & $63-68$ & 2 & 6,45 \\
\hline \multicolumn{2}{|c|}{ Total } & 31 & 100 \\
\hline
\end{tabular}

Berdasarkan hasil deskripsi data variabel kepemimpinan spiritual (X3) diketahui: rerata 50,52; deviasi standar 5,55; skor maksimum 60; skor minimum 37; range 23; dan interval 6 . Adapun deskripsi frekuensi variabel kepemimpinan spiritual (X3) disajikan pada Tabel 3.

Tabel 3 Distribusi Frekuensi Variabel Kepemimpinan Spiritual (X3)

\begin{tabular}{|c|c|c|c|}
\hline Kategori & Interval & f & $\%$ \\
\hline Sangat rendah & $37-42$ & 1 & 3,23 \\
\hline Rendah & $43-48$ & 10 & 32,26 \\
\hline Cukup & $49-54$ & 11 & 35,48 \\
\hline Tinggi & $55-60$ & 9 & 29,03 \\
\hline Sangat tinggi & $61-66$ & 0 & 0,00 \\
\hline \multicolumn{2}{|c|}{ Total } & 31 & 100 \\
\hline
\end{tabular}

Berdasarkan hasil deskripsi data variabel budaya sekolah (X4) diketahui: rerata 116; deviasi standar 8,27; skor maksimum 129; skor minimum 97; range 32; dan interval 8. Adapun deskripsi frekuensi variabel budaya sekolah (X4) disajikan pada Tabel 4.

Tabel 4 Distribusi Frekuensi Variabel Budaya Sekolah (X4)

\begin{tabular}{|c|c|c|c|}
\hline Kategori & Interval & f & $\%$ \\
\hline Sangat rendah & $97-104$ & 3 & 9,68 \\
\hline Rendah & $105-112$ & 7 & 22,58 \\
\hline Cukup & $113-120$ & 10 & 32,26 \\
\hline Tinggi & $121-128$ & 10 & 32,26 \\
\hline Sangat tinggi & $128-135$ & 1 & 3,23 \\
\hline \multicolumn{2}{|c|}{ Total } & 31 & 100 \\
\hline
\end{tabular}

Berdasarkan hasil deskripsi data variabel etika profesi (X5) diketahui: rerata 78,84; deviasi standar 6,62; skor maksimum 93; skor minimum 64; range 29; dan interval 7. Adapun deskripsi frekuensi variabel etika profesi (X5) disajikan pada Tabel 5.

Tabel 5 Distribusi Frekuensi Variabel Etika Profesi (X5)

\begin{tabular}{|c|c|c|c|}
\hline Kategori & Interval & f & $\%$ \\
\hline Sangat rendah & $64-70$ & 2 & 6,45 \\
\hline Rendah & $71-77$ & 14 & 45,16 \\
\hline Cukup & $78-84$ & 8 & 25,81 \\
\hline Tinggi & $85-91$ & 6 & 19,35 \\
\hline Sangat tinggi & $92-98$ & 1 & 3,23 \\
\hline \multicolumn{2}{|c|}{ Total } & 31 & 100 \\
\hline
\end{tabular}

Berdasarkan hasil deskripsi data variabel kinerja mengajar guru (Y) diketahui: rerata 120,20; deviasi standar 12,22; skor maksimum 138; skor minimum 96; range 42; dan interval 11. Adapun deskripsi frekuensi variabel kinerja mengajar guru (Y) disajikan pada Tabel 6. 
Tabel 6 Distribusi Frekuensi Variabel Kinerja Mengajar Guru (Y)

\begin{tabular}{|c|c|c|c|}
\hline Kategori & Interval & f & $\%$ \\
\hline Sangat rendah & $96-106$ & 3 & 15 \\
\hline Rendah & $107-117$ & 4 & 20 \\
\hline Cukup & $118-128$ & 7 & 35 \\
\hline Tinggi & $129-139$ & 6 & 30 \\
\hline Sangat tinggi & $140-150$ & 0 & 0 \\
\hline \multicolumn{2}{|c|}{ Total } & 20 & 100 \\
\hline
\end{tabular}

\section{Deskripsi Data SMP Assa'adah Gresik}

Berdasarkan hasil deskripsi data variabel kepemimpinan pembelajaran (X1) diketahui: rerata 61,42; deviasi standar 6,46; skor maksimum 72; skor minimum 52; range 20; dan interval 5. Adapun deskripsi frekuensi variabel kepemimpinan pembelajaran (X1) disajikan pada Tabel 7.

Tabel 7 Distribusi Frekuensi Variabel Kepemimpinan Pembelajaran (X1)

\begin{tabular}{|c|c|c|c|}
\hline Kategori & Interval & f & $\%$ \\
\hline Sangat rendah & $52-56$ & 6 & 19,35 \\
\hline Rendah & $57-61$ & 13 & 41,94 \\
\hline Cukup & $62-66$ & 4 & 12,90 \\
\hline Tinggi & $67-71$ & 5 & 16,13 \\
\hline Sangat tinggi & $72-76$ & 3 & 9,68 \\
\hline \multicolumn{2}{|c|}{ Total } & 31 & 100 \\
\hline
\end{tabular}

Berdasarkan hasil deskripsi data variabel kepemimpinan perubahan (X2) diketahui: rerata 52,65; deviasi standar 5,64; skor maksimum 63; skor minimum 42; range 21; dan interval 5. Adapun deskripsi frekuensi variabel kepemimpinan perubahan (X2) disajikan pada Tabel 8.

Tabel 8 Distribusi Frekuensi Variabel Kepemimpinan Perubahan (X2)

\begin{tabular}{lccc}
\hline \multicolumn{1}{c}{ Kategori } & Interval & f & \% \\
\hline Sangat rendah & $42-46$ & 5 & 16,13 \\
Rendah & $47-51$ & 10 & 32,26 \\
Cukup & $52-56$ & 9 & 29,03 \\
Tinggi & $57-61$ & 4 & 12,90 \\
Sangat tinggi & $62-66$ & 3 & 9,68 \\
\hline Total & & $\mathbf{3 1}$ & $\mathbf{1 0 0}$ \\
\hline
\end{tabular}

Berdasarkan hasil deskripsi data variabel kepemimpinan spiritual (X3) diketahui: rerata 49,35; deviasi standar 5,44; skor maksimum 58; skor minimum 38; range 20; dan interval 5. Adapun deskripsi frekuensi variabel kepemimpinan spiritual (X3) disajikan pada Tabel 9.

Tabel 9 Distribusi Frekuensi Variabel Kepemimpinan Spiritual (X3)

\begin{tabular}{|c|c|c|c|}
\hline Kategori & Interval & f & $\%$ \\
\hline Sangat rendah & $38-44$ & 5 & 16,13 \\
\hline Rendah & $45-49$ & 13 & 41,94 \\
\hline Cukup & $50-54$ & 5 & 16,13 \\
\hline Tinggi & $55-59$ & 8 & 25,81 \\
\hline Sangat tinggi & $60-64$ & 0 & 0,00 \\
\hline \multicolumn{2}{|c|}{ Total } & 31 & 100 \\
\hline
\end{tabular}


Berdasarkan hasil deskripsi data variabel budaya sekolah (X4) diketahui: rerata 109,55; deviasi standar 10,39; skor maksimum 132; skor minimum 91; range 41; dan interval 10. Adapun deskripsi frekuensi variabel budaya sekolah (X4) disajikan pada Tabel 10.

Tabel 10 Distribusi Frekuensi Variabel Budaya Sekolah (X4)

\begin{tabular}{|c|c|c|c|}
\hline Kategori & Interval & f & $\%$ \\
\hline Sangat rendah & $91-100$ & 8 & 25,81 \\
\hline Rendah & $101-110$ & 10 & 32,26 \\
\hline Cukup & $111-120$ & 7 & 22,58 \\
\hline Tinggi & $121-130$ & 4 & 12,90 \\
\hline Sangat tinggi & $131-140$ & 2 & 6,45 \\
\hline \multicolumn{2}{|c|}{ Total } & 31 & 100 \\
\hline
\end{tabular}

Berdasarkan hasil deskripsi data variabel etika profesi (X5) diketahui: rerata 76,97; deviasi standar 6,95; skor maksimum 92; skor minimum 63; range 29; dan interval 7. Adapun deskripsi frekuensi variabel etika profesi (X5) disajikan pada Tabel 11.

Tabel 11 Distribusi Frekuensi Variabel Etika Profesi (X5)

\begin{tabular}{|c|c|c|c|}
\hline Kategori & Interval & f & $\%$ \\
\hline Sangat rendah & $63-69$ & 4 & 12,90 \\
\hline Rendah & $70-76$ & 12 & 38,71 \\
\hline Cukup & $77-83$ & 9 & 29,03 \\
\hline Tinggi & $84-90$ & 4 & 12,90 \\
\hline Sangat tinggi & $91-97$ & 2 & 6,45 \\
\hline \multicolumn{2}{|c|}{ Total } & 31 & 100 \\
\hline
\end{tabular}

Berdasarkan hasil deskripsi data variabel kinerja mengajar guru (Y) diketahui: rerata 120,25; deviasi standar 11,39; skor maksimum 144; skor minimum 108; range 36; dan interval 9. Adapun deskripsi frekuensi variabel kinerja mengajar guru (Y) disajikan pada Tabel 12.

Tabel 12 Distribusi Frekuensi Variabel Kinerja Mengajar Guru (Y)

\begin{tabular}{|c|c|c|c|}
\hline Kategori & Interval & f & $\%$ \\
\hline Sangat rendah & $108-116$ & 8 & 40 \\
\hline Rendah & $117-125$ & 7 & 35 \\
\hline Cukup & $126-134$ & 3 & 15 \\
\hline Tinggi & $135-143$ & 2 & 10 \\
\hline Sangat tinggi & $144-152$ & 0 & 0 \\
\hline \multicolumn{2}{|c|}{ Total } & 20 & 100 \\
\hline
\end{tabular}

\section{SMP Insan Terpadu Probolinggo}

Berdasarkan hasil deskripsi data variabel kepemimpinan pembelajaran (X1) diketahui: rerata 61,18; deviasi standar 7,23; skor maksimum 72; skor minimum 47; range 25; dan interval 6 . Adapun deskripsi frekuensi variabel kepemimpinan pembelajaran (X1) disajikan pada Tabel 13.

Tabel 13 Distribusi Frekuensi Variabel Kepemimpinan Pembelajaran (X1)

\begin{tabular}{|c|c|c|c|}
\hline Kategori & Interval & f & $\%$ \\
\hline Sangat rendah & $47-52$ & 3 & 13,64 \\
\hline Rendah & $53-58$ & 6 & 27,27 \\
\hline Cukup & $59-64$ & 4 & 18,18 \\
\hline Tinggi & $65-70$ & 7 & 31,82 \\
\hline Sangat tinggi & $71-76$ & 2 & 9,09 \\
\hline \multicolumn{2}{|c|}{ Total } & 22 & 100 \\
\hline
\end{tabular}


Berdasarkan hasil deskripsi data variabel kepemimpinan perubahan (X2) diketahui: rerata 52; deviasi standar 7,75; skor maksimum 64; skor minimum 27; range 37; dan interval 9. Adapun deskripsi frekuensi variabel kepemimpinan perubahan (X2) disajikan pada Tabel 14.

Tabel 14 Distribusi Frekuensi Variabel Kepemimpinan Perubahan (X2)

\begin{tabular}{|c|c|c|c|}
\hline Kategori & Interval & f & $\%$ \\
\hline Sangat rendah & $27-35$ & 1 & 4,55 \\
\hline Rendah & $36-44$ & 0 & 0,00 \\
\hline Cukup & $45-53$ & 12 & 54,55 \\
\hline Tinggi & $54-62$ & 7 & 31,82 \\
\hline Sangat tinggi & $63-71$ & 2 & 9,09 \\
\hline \multicolumn{2}{|c|}{ Total } & 22 & 100 \\
\hline
\end{tabular}

Berdasarkan hasil deskripsi data variabel kepemimpinan spiritual (X3) diketahui: rerata 48,55; deviasi standar 7,47; skor maksimum 60; skor minimum 27; range 33; dan interval 8 . Adapun deskripsi frekuensi variabel kepemimpinan spiritual (X3) disajikan pada Tabel 15.

Tabel 15 Distribusi Frekuensi Variabel Kepemimpinan Spiritual (X3)

\begin{tabular}{|c|c|c|c|}
\hline Kategori & Interval & f & $\%$ \\
\hline Sangat rendah & $27-34$ & 1 & 4,55 \\
\hline Rendah & $35-42$ & 1 & 4,55 \\
\hline Cukup & $43-50$ & 11 & 50,00 \\
\hline Tinggi & $51-58$ & 8 & 36,36 \\
\hline Sangat tinggi & $59-66$ & 1 & 4,55 \\
\hline \multicolumn{2}{|c|}{ Total } & 22 & 100 \\
\hline
\end{tabular}

Berdasarkan hasil deskripsi data variabel budaya sekolah (X4) diketahui: rerata 116,23; deviasi standar 11,67; skor maksimum 135; skor minimum 99; range 36; dan interval 9. Adapun deskripsi frekuensi variabel budaya sekolah (X4) disajikan pada Tabel 16.

Tabel 16 Distribusi Frekuensi Variabel Budaya Sekolah (X4)

\begin{tabular}{|c|c|c|c|}
\hline Kategori & Interval & $\mathbf{f}$ & $\%$ \\
\hline Sangat rendah & $99-107$ & 7 & 31,82 \\
\hline Rendah & $108-116$ & 4 & 18,18 \\
\hline Cukup & $117-125$ & 7 & 31,82 \\
\hline Tinggi & $126-134$ & 3 & 13,64 \\
\hline Sangat tinggi & $135-143$ & 1 & 4,55 \\
\hline \multicolumn{2}{|c|}{ Total } & 22 & 100 \\
\hline
\end{tabular}

Berdasarkan hasil deskripsi data variabel etika profesi (X5) diketahui: rerata 85,41; deviasi standar 7,69; skor maksimum 100; skor minimum 72; range 28; dan interval 7. Adapun deskripsi frekuensi variabel etika profesi (X5) disajikan pada Tabel 17.

Tabel 17 Distribusi Frekuensi Variabel Etika Profesi (X5)

\begin{tabular}{lccc}
\hline \multicolumn{1}{c}{ Kategori } & Interval & f & \% \\
\hline Sangat rendah & $72-78$ & 4 & 18,18 \\
Rendah & $79-85$ & 8 & 36,36 \\
Cukup & $86-92$ & 6 & 27,27 \\
Tinggi & $93-99$ & 2 & 9,09 \\
Sangat tinggi & $100-106$ & 2 & 9,09 \\
\hline Total & & $\mathbf{2 2}$ & $\mathbf{1 0 0}$ \\
\hline
\end{tabular}


Berdasarkan hasil deskripsi data variabel kinerja mengajar guru (Y) diketahui: rerata 124,06; deviasi standar 11,74; skor maksimum 142; skor minimum 108; range 34; dan interval 9. Adapun deskripsi frekuensi variabel kinerja mengajar guru (Y) disajikan pada Tabel 18.

Tabel 18 Distribusi Frekuensi Variabel Kinerja Mengajar Guru (Y)

\begin{tabular}{|c|c|c|c|}
\hline Kategori & Interval & f & $\%$ \\
\hline Sangat rendah & $108-116$ & 5 & 29,41 \\
\hline Rendah & $117-125$ & 3 & 17,65 \\
\hline Cukup & $126-134$ & 6 & 35,29 \\
\hline Tinggi & $135-143$ & 3 & 17,65 \\
\hline Sangat tinggi & $144-152$ & 0 & 0,00 \\
\hline \multicolumn{2}{|c|}{ Total } & 17 & 100 \\
\hline
\end{tabular}

\section{Deskripsi Data Kompilasi}

Setelah mendeskripsikan data penelitian setiap sekolah, selanjutnya mendeskripsikan data penelitian kompilasi ketiga sekolah. Berdasarkan hasil deskripsi data variabel kepemimpinan pembelajaran (X1) diketahui: rerata 61,79; deviasi standar 6,34; skor maksimum 72; skor minimum 47; range 25; dan interval 6. Adapun deskripsi frekuensi variabel kepemimpinan pembelajaran (X1) disajikan pada Tabel 19.

Tabel 19 Distribusi Frekuensi Variabel Kepemimpinan Pembelajaran (X1)

\begin{tabular}{|c|c|c|c|}
\hline Kategori & Interval & f & $\%$ \\
\hline Sangat rendah & $47-52$ & 8 & 9,52 \\
\hline Rendah & $53-58$ & 20 & 23,81 \\
\hline Cukup & $59-64$ & 24 & 28,57 \\
\hline Tinggi & $65-69$ & 21 & 25,00 \\
\hline Sangat tinggi & $70-75$ & 11 & 13,10 \\
\hline
\end{tabular}

Berdasarkan hasil deskripsi data variabel kepemimpinan perubahan (X2) diketahui: rerata 52,43; deviasi standar 6,23; skor maksimum 64; skor minimum 27; range 37; dan interval 9. Adapun deskripsi frekuensi variabel kepemimpinan perubahan (X2) disajikan pada Tabel 20.

Tabel 20 Distribusi Frekuensi Variabel Kepemimpinan Perubahan (X2)

\begin{tabular}{|c|c|c|c|}
\hline Kategori & Interval & f & $\%$ \\
\hline Sangat rendah & $27-35$ & 1 & 1,19 \\
\hline Rendah & $36-44$ & 4 & 4,76 \\
\hline Cukup & $45-53$ & 44 & 52,38 \\
\hline Tinggi & $54-62$ & 30 & 35,71 \\
\hline Sangat tinggi & $63-71$ & 5 & 5,95 \\
\hline \multicolumn{2}{|c|}{ Total } & 84 & 100 \\
\hline
\end{tabular}

Berdasarkan hasil deskripsi data variabel kepemimpinan spiritual (X3) diketahui: rerata 49,57; deviasi standar 6,05; skor maksimum 60; skor minimum 27; range 33; dan interval 8 . Adapun deskripsi frekuensi variabel kepemimpinan spiritual (X3) disajikan pada Tabel 21. 
Tabel 21 Distribusi Frekuensi Variabel Kepemimpinan Spiritual (X3)

\begin{tabular}{|c|c|c|c|}
\hline Kategori & Interval & f & $\%$ \\
\hline Sangat rendah & $27-34$ & 1 & 1,19 \\
\hline Rendah & $34-41$ & 4 & 4,76 \\
\hline Cukup & $42-49$ & 40 & 47,62 \\
\hline Tinggi & $50-57$ & 31 & 36,90 \\
\hline Sangat tinggi & $58-65$ & 8 & 9,52 \\
\hline \multicolumn{2}{|c|}{ Total } & 84 & 100 \\
\hline
\end{tabular}

Berdasarkan hasil deskripsi data variabel budaya sekolah (X4) diketahui: rerata 113,68; deviasi standar 10,41; skor maksimum 135; skor minimum 91; range 44; dan interval 11. Adapun deskripsi frekuensi variabel budaya sekolah (X4) disajikan pada Tabel 22.

Tabel 22 Distribusi Frekuensi Variabel Budaya Sekolah (X4)

\begin{tabular}{|c|c|c|c|}
\hline Kategori & Interval & f & $\%$ \\
\hline Sangat rendah & $91-101$ & 13 & 15,48 \\
\hline Rendah & $102-112$ & 25 & 29,76 \\
\hline Cukup & $113-123$ & 31 & 36,90 \\
\hline Tinggi & $124-134$ & 14 & 16,67 \\
\hline Sangat tinggi & $135-145$ & 1 & 1,19 \\
\hline \multicolumn{2}{|c|}{ Total } & 84 & 100 \\
\hline
\end{tabular}

Berdasarkan hasil deskripsi data variabel etika profesi (X5) diketahui: rerata 79,87; deviasi standar 7,74; skor maksimum 100; skor minimum 63; range 37; dan interval 9. Adapun deskripsi frekuensi variabel etika profesi (X5) disajikan pada Tabel 23.

Tabel 23 Distribusi Frekuensi Variabel Etika Profesi (X5)

\begin{tabular}{|c|c|c|c|}
\hline Kategori & Interval & $\mathbf{f}$ & $\%$ \\
\hline Sangat rendah & $63-71$ & 8 & 9,52 \\
\hline Rendah & $72-80$ & 42 & 50,00 \\
\hline Cukup & $81-89$ & 24 & 28,57 \\
\hline Tinggi & $90-98$ & 8 & 9,52 \\
\hline Sangat tinggi & $98-106$ & 2 & 2,38 \\
\hline \multicolumn{2}{|c|}{ Total } & 84 & 100 \\
\hline
\end{tabular}

Berdasarkan hasil deskripsi data variabel kinerja mengajar guru (Y) diketahui: rerata 121,37; deviasi standar 11,71; skor maksimum 144; skor minimum 96; range 48; dan interval 12. Adapun deskripsi frekuensi variabel kinerja mengajar guru (Y) disajikan pada Tabel 24.

Tabel 24 Distribusi Frekuensi Variabel Kinerja Mengajar Guru (Y)

\begin{tabular}{|c|c|c|c|}
\hline Kategori & Interval & f & $\%$ \\
\hline Sangat rendah & $96-107$ & 3 & 5,26 \\
\hline Rendah & $108-119$ & 21 & 36,84 \\
\hline Cukup & $120-131$ & 20 & 35,09 \\
\hline Tinggi & $132-143$ & 11 & 19,30 \\
\hline Sangat tinggi & $144-155$ & 2 & 3,51 \\
\hline \multicolumn{2}{|c|}{ Total } & 57 & 100 \\
\hline
\end{tabular}




\section{Uji Asumsi Data}

Sebelum data dianalisis dengan regresi, terlebih dahulu data diuji asumsi normalitas, homogenitas, dan linieritas. Uji normalitas untuk memastikan bahwa data penelitian berdistribusi normal. Uji normalitas dengan menggunakan Kolmogorov-Smirnov Test. Hasil uji Kolmogorov-Smirnov Test menunjukkan signifikansi dari variabel: kepemimpinan pembelajaran $=0,630$; kepemimpinan perubahan $=0,598$; kepemimpinan spiritual $=0,449$; budaya sekolah $=0,469$; etika profesi $=0,207$; dan kinerja mengajar guru $=0,570$. Berdasarkan uji signifikansi koefisien Kolmogorov-Smirnov Test semua variabel penelitian $>0,050$; sehingga disimpulkan data termasuk dalam distribusi normal.

Uji homogenitas digunakan untuk memastikan data penelitian dari sampel yang memiliki varians kecil. Uji homogenitas dengan menggunakan Test of Homogeneity of Variances. Hasil uji Test of Homogeneity of Variances menunjukkan signifikansi dari variabel: kepemimpinan pembelajaran $=$ 0,252 ; kepemimpinan perubahan $=0,611$; kepemimpinan spiritual $=0,548$; budaya sekolah $=0,060$; etika profesi $=0,740$; dan kinerja mengajar guru $=0,543$. Berdasarkan uji signifikansi koefisien Test of Homogeneity of Variances semua variabel penelitian $>0,050$; sehingga disimpulkan data berasal dari sampel yang memiliki varians kecil.

Uji linieritas digunakan untuk memastikan data penelitian variabel prediktor memiliki hubungan yang linier dengan variabel kriterium, artinya jika prediktor terjadi kenaikan maka kriterium juga naik, dan begitu pula sebaliknya. Uji linieritas dengan menggunakan kooefisien Curve Estimation. Hasil uji Curve Estimation menunjukkan signifikansi dari variabel: kepemimpinan pembelajaran $=0,000$; kepemimpinan perubahan $=0,000$; kepemimpinan spiritual $=0,000$; budaya sekolah $=0,000$; etika profesi $=0,000$; dan kinerja mengajar guru $=0,000$. Berdasarkan uji signifikansi koefisien Curve Estimation semua variabel penelitian $<0,050$; sehingga disimpulkan semua variabel prediktor memiliki hubungan linier dengan variabel kriterium.

Berdasarkan uji asumsi terhadap data penelitian yang meliputi uji normalitas, homogenitas, dan linieritas dapat disimpulkan data penelitian memenuhi asumsi data untuk dianalisis dengan statistika parametrik (analisis regresi). Selanjutnya berikut ini dipaparkan hasil dari analisis data dengan menggunakan analisis regresi.

\section{Analisis Regresi}

Analisis regresi merupakan analisis yang menjelaskan tentang akibat-akibat dan besarnya akibat yang ditimbulkan oleh satu atau lebih variabel prediktor terhadap satu variabel kriterium. Berdasarkan hasil analisis regresi, signifikansi uji $\mathrm{F}=0,000<0,050$; sehingga hipotesis yang menyatakan ada pengaruh yang signifikan kepemimpinan pembelajaran, kepemimpinan perubahan, kepemimpinan spiritual, budaya sekolah, dan etika profesi terhadap kinerja mengajar guru Sekolah Menengah Pertama (SMP) berbasis pesantren di Jawa Timur, diterima.

Tabel 25 Coefficients

\begin{tabular}{rrrrrrr}
\hline \multirow{2}{*}{ Model } & \multicolumn{2}{c}{ Unstandardized Coefficients } & \multicolumn{2}{c}{$\begin{array}{c}\text { Standardized } \\
\text { Coefficients } \\
\text { Beta }\end{array}$} & f & Sig. \\
\cline { 3 - 4 } & \multicolumn{1}{c}{ B } & \multicolumn{1}{c}{ Std. Error } & & \\
\hline 1 & (Constant) & 161.323 & 21.420 & & 7.531 & .000 \\
& X1 & .291 & .400 & .153 & .726 & .471 \\
X2 & .304 & .413 & .171 & .737 & .464 \\
X3 & .621 & .279 & .330 & 2.226 & .030 \\
X4 & .363 & .183 & .319 & 1.978 & .053 \\
X5 & .029 & .213 & .020 & .135 & .893 \\
\hline
\end{tabular}

Hasil penelitian menyimpulkan ada pengaruh yang signifikan kepemimpinan pembelajaran, kepemimpinan perubahan, kepemimpinan spiritual, budaya sekolah, dan etika profesi terhadap kinerja mengajar guru Sekolah Menengah Pertama (SMP) berbasis pesantren di Jawa Timur. Selanjutnya dari 
hasil analisis regresi dicari persamaan regresi yang terbentuk. Hasil persamaan regresi mengacu pada analisis regresi ganda yakni pada Tabel 25 Coefficientsa. Persamaan regresi yang terbentuk adalah:

$$
\hat{Y}=161,323+0,291 X 1+0,304 X 2+0,621 X 3+0,363 X 4+0,029 X 5
$$

Interpretasi model berdasarkan formula persamaan regresi tersebut adalah:

- Nilai a $=161,323$. Hal ini berarti jika X1, X2, X3, X4, dan X5 konstan, maka Y =161,323 satuan;

- Nilai b1 =0,291. Hal ini berarti jika nilai variabel X1 meningkat satu satuan, sementara nilai variabel X2, X3, X4, dan X5 bersifat tetap, maka variabel Y akan meningkat sebesar 0,291 satuan;

- Nilai b2 =0,304. Hal ini berarti jika nilai variabel X2 meningkat satu satuan, sementara nilai variabel X1, X3, X4, dan X5 bersifat tetap, maka variabel Y akan meningkat sebesar 0,304 satuan;

- Nilai b3 =0,621. Hal ini berarti jika nilai variabel X3 meningkat satu satuan, sementara nilai variabel X1, X2, X4, dan X5 bersifat tetap, maka variabel Y akan meningkat sebesar 0,621 satuan;

- Nilai b4 =0,363. Hal ini berarti jika nilai variabel X4 meningkat satu satuan, sementara nilai variabel X1, X2, X3, dan X5 bersifat tetap, maka variabel Y akan meningkat sebesar 0,363 satuan;

- Nilai b5 =0,029. Hal ini berarti jika nilai variabel X5 meningkat satu satuan, sementara nilai variabel X1, X2, X3, dan X4 bersifat tetap, maka variabel Y akan meningkat sebesar 0,029 satuan.

\section{Kepemimpinan Pembelajaran}

Peran kepala sekolah dalam kepemimpinan instruksional sangat krusial dalam menetapkan arah sekolah. Dimensi misi berfokus pada peran kepala sekolah dalam bekerja sama dengan staf, memastikan sekolah terus berjalan pada tujuan yang jelas, terukur, dan berdasarkan waktu yang menghasilkan kemajuan akademik siswa (Lynch, 2015; Pambudi \& Gunawan, 2019). Kepala sekolah bertanggung jawab untuk mengkomunikasikan tujuan, yang harus diketahui secara luas dan didukung di seluruh sekolah. Proses pengembangan tujuan tidak dipertimbangkan; kepentingannya kurang penting daripada memenuhi hasil kinerja. Ini merupakan kelemahan dalam model. Penelitian hanya menerima bahwa tujuan harus ditetapkan oleh kepala sekolah, bekerja sama dengan staf, untuk mencapai efektivitas.

Memastikan bahwa staf memasukkan sasaran kinerja ke dalam rutinitas harian mereka adalah penting dalam kepemimpinan instruksional. Sasaran yang kabur dan tidak jelas harus dikesampingkan, demi memperjelas garis pemisah antara upaya yang berfokus secara akademis dan mata pelajaran yang diujikan. Sebuah contoh yang bagus dari masalah pengujian standar dapat menyebabkan di sekolah dicatat dalam sebuah studi oleh Hallinger \& Murphy (1985). Guru di sekolah efektif diamati saat mengajar. Seorang guru memiliki pusat kegiatan unik yang terletak di belakang kelas, tetapi Hallinger \& Murphy (1985) mengamati bahwa siswa tidak bekerja di pusat tersebut selama periode kelas.

Ketika ditanya, guru menyatakan bahwa, meskipun dia benar-benar menyukai pusat kegiatan, dia tidak punya waktu untuk menggunakannya, karena kelas belum membuat kemajuan yang diperlukan dalam mata pelajaran dasar. Hallinger \& Murphy (1985) kemudian melaporkan bahwa kepala sekolahnya berharap para guru menghabiskan lebih banyak waktu untuk membaca, mengeja, menulis, dan matematika daripada yang diperlukan untuk mencapai kemajuan yang diharapkan dalam mata pelajaran dasar. Kepala sekolah menyatakan kembali harapan ini hampir kata demi kata ketika ditanya.

Poin-poin berikut ini menggambarkan praktik terbaik untuk menggunakan kepemimpinan 
pembelajaran untuk mendefinisikan misi sekolah: (1) tujuan administrator secara jelas diungkapkan dan dimodelkan, secara tertulis, di sekitar sekolah, semua guru dan administrator menggunakan bahasa yang sama untuk membahas prioritas akademik; (2) guru memberikan status prioritas pada misi sekolah dalam perencanaan dan pelaksanaan pelajaran; dan (3) tujuannya diartikulasikan dengan baik, didukung secara aktif, dan dimodelkan oleh administrator sekolah (Lynch, 2015; Argadinata \& Gunawan, 2019). Para pemimpin pembelajaran dapat menerapkan penelitian ini pada strategi pembangunan misi mereka. Pertanyaan yang diajukan kepala sekolah saat menentukan tujuan sekolah adalah: (1) apakah tujuannya jelas dan mudah dimengerti; (2) apakah mereka ditulis dan diketahui oleh semua orang di sekolah; (3) apakah tujuan berlaku dalam kegiatan sehari-hari di sekolah; (4) apakah saya secara konstan dan aktif memperkuat dan menjelaskan tujuan-tujuan ini; dan (5) apakah tujuan mendapat dukungan dari seluruh sekolah?

\section{Kepemimpinan Perubahan}

Kepemimpinan perubahan adalah jenis kepemimpinan yang berfokus pada perubahan skala besar dalam suatu organisasi. Pemimpin perubahan lebih peduli tentang visi transformatif besar untuk bisnis dan bagaimana staf menjadi cukup diberdayakan untuk berkontribusi pada penciptaan visi itu (Lares, 2019). Namun, satu risiko perubahan kepemimpinan adalah memiliki potensi untuk keluar dari kendali dan tidak memperhitungkan gangguan yang lebih kecil di bidang pekerjaan. Selain itu, perusahaan tidak boleh bertindak atas perubahan apa pun yang diusulkan pada struktur yang telah ditentukan. Kepemimpinan perubahan jarang datang dari atas karena orang-orang yang terlibat memiliki insentif paling kecil untuk mendorong perubahan besar dan luar biasa yang meluas hingga staf terkecil. Sebagian besar pemimpin perubahan berasal dari posisi manajemen menengah.

Namun, ada kekurangan pemimpin perubahan karena sebagian besar posisi manajemen tradisional dan lebih mirip dengan manajer perubahan. Para ahli berpendapat bahwa kekurangan tersebut dapat diakhiri dengan membawa bakat luar yang berspesialisasi dalam perubahan nyata dan menginstruksikan manajer tentang metode perubahan kepemimpinan. Kepemimpinan perubahan yang tepat dapat melambungkan organisasi melalui ketidakpastian ke kepastian - melalui kebingungan dan gangguan menuju tingkat kesuksesan yang sama sekali baru. Tidak ada pekerjaan yang lebih sulit untuk pemimpin selain memimpin perubahan semacam ini. Jeff Bezos menyatakan pemimpin akan mendapatkan reputasi dengan berusaha melakukan hal-hal sulit dengan baik (Bradham, 2017; Saputra, dkk., 2019).

Kepemimpinan perubahan berbeda dengan manajemen perubahan. Manajemen perubahan adalah proses yang didorong oleh model atau metodologi untuk mengendalikan dan mengkomunikasikan perubahan. Kontrol adalah kata kunci di sini. Tujuan dari manajemen perubahan adalah untuk meluncur melalui transisi dengan gangguan minimal. Kepemimpinan perubahan meningkatkan gangguan untuk menginspirasi - untuk memicu dan mempertahankan perubahan. Gangguan ini mengatur panggung untuk inovasi dan transformasi. Sementara ada banyak tulisan tentang model manajemen perubahan dari sejumlah konsultan dan pakar, model untuk kepemimpinan perubahan terus berkembang.

Dengan tidak adanya model yang jelas, subjek kepemimpinan perubahan telah menarik mistik tertentu. John Kotter menganalogikan kepemimpinan perubahan menjadi mesin 1.000 tenaga kuda (Bradham, 2017). Dengan banyak kekuatan di belakangnya, mengubah kepemimpinan bisa sedikit di luar kendali. Apa yang diinginkan, John Kotter menyimpulkan adalah pengemudi yang sangat terampil dan seorang pengemudi mobil (Bradham, 2017). Deskripsi kepemimpinan perubahan ini mungkin terdengar menarik. Tetapi itu juga cenderung menggoyahkan kepercayaan sebagian besar pemimpin. Terutama ketika Kotter menambahkan bahwa, meskipun mengubah kepemimpinan adalah tantangan besar di masa depan, hampir tidak ada yang sangat pandai dalam hal itu (Bradham, 2017). Tetapi perubahan harus dan akan terus terjadi, dan sudah saatnya organisasi menjadi lebih baik. 


\section{Kepemimpinan Spiritual}

Spiritual berkaitan dengan sifat-sifat roh manusia dan realitas tak berwujud sebagai inti kepribadian, prinsip kehidupan yang menjiwai atau nafas kehidupan yang mengingatkan manusia untuk mencari dimensi terdalam dari pengalaman manusia. Spiritual adalah inti dari pencarian transendensi-diri dan perasaan saling keterkaitan dengan semua hal di alam semesta. Spiritual adalah asumsi yang melekat pada spiritualitas yang mendasari tradisi spiritual dan agama dunia (Fry \& Kriger, 2009; Gunawan, 2019). Berdasarkan perspektif tersebut, sebuah agama memusatkan perhatian pada sistem kepercayaan, doa ritual, ritual, dan upacara teologis, serta praktik dan gagasan formal yang terkait. Biasanya, agama dipraktikkan di lembaga-lembaga yang telah terbentuk dan berkembang dari waktu ke waktu di sekitar pengalaman spiritual satu atau lebih individu pendiri yang juga menyediakan konteks kepemimpinan berdasarkan keyakinan dan praktik yang melekat dalam agama itu.

Namun, spiritualitas bukan hanya tentang mengembangkan hubungan pribadi dengan kehadiran ilahi. Ini juga mendasar bagi definisi yang paling diterima luas tentang spiritualitas tempat kerja, yaitu kerangka kerja nilai-nilai organisasi yang dibuktikan dalam budaya yang mempromosikan pengalaman transendensi staf melalui proses kerja, memfasilitasi perasaan mereka untuk terhubung dengan cara yang memberikan perasaan belas kasih dan sukacita (Giacalone \& Jurkiewicz, 2003; Sultoni, dkk., 2018a; Sultoni, dkk., 2018b). Penelitian telah menunjukkan bahwa ada konsistensi yang jelas antara nilai-nilai dan praktik spiritual, dan efektivitas kepemimpinan dan nilai-nilai yang telah lama dianggap cita-cita spiritual, seperti integritas, kejujuran, dan kerendahan hati, memiliki pengaruh positif terhadap keberhasilan kepemimpinan. Ini menunjukkan bahwa memuaskan kebutuhan-kebutuhan spiritual ini di tempat kerja secara positif memengaruhi kesehatan manusia dan kesejahteraan psikologis, dan membentuk landasan bagi spiritualitas tempat kerja maupun kepemimpinan spiritual.

Kepemimpinan spiritual dapat dipandang sebagai paradigma yang muncul dalam bidang spiritualitas tempat kerja yang lebih luas. Hal ini dipandang perlu untuk menciptakan visi dan nilai kesesuaian di tingkat individu, tim dan organisasi yang diberdayakan dan dapat diterapkan dalam organisasi keagamaan dan sekuler (Fry, 2003; Fry \& Egel, 2017). Kepemimpinan spiritual secara intrinsik memotivasi dan menginspirasi para pekerja melalui harapan / keyakinan dalam visi yang transenden dan budaya perusahaan berdasarkan nilai-nilai altruistik untuk memenuhi kebutuhan universal akan kesejahteraan spiritual melalui panggilan dan keanggotaan dan, pada akhirnya, memaksimalkan komitmen, produktivitas, dan kepuasan staf.

Penting dalam kepemimpinan spiritual untuk membedakan antara kepemimpinan dan pemimpin. Pengembangan pemimpin berfokus pada individu untuk mengembangkan pengetahuan, keterampilan, dan kemampuan berbasis individu yang terkait dengan peran kepemimpinan formal. Ini sering berpusat pada keterampilan dan kemampuan intrapersonal seperti kesadaran diri, pengaturan diri, dan motivasi diri. Kepemimpinan biasanya berkonsentrasi pada pengaruh yang dimiliki pemimpin di antara pengikut mereka dengan fokus utama pada proses pengaruh sosial yang melibatkan semua orang dan memungkinkan kelompok orang untuk bekerja bersama dengan cara yang bermakna. Ini melibatkan pembangunan kapasitas untuk kesejahteraan individu dan kolektif yang lebih baik, kemampuan beradaptasi, dan kinerja di berbagai situasi.

Tantangan ketika menerapkan kepemimpinan spiritual di tingkat organisasi adalah konotasi negatif yang terkait dengan istilah spiritual. Organisasi sekuler mungkin menginginkan istilah netral untuk model kepemimpinan untuk menghindari reaksi negatif dari mereka yang mungkin mengaitkan kata spiritual dengan agama. Kekhawatiran muncul terkait ekspresi keyakinan staf dan pemimpin tanpa penilaian sementara menyeimbangkan hak hukum masing-masing pihak terbukti menantang. Secara khusus, membina program sukarela yang melegitimasi dan memelihara kehidupan batin staf dipandang penting untuk menerapkan kepemimpinan spiritual organisasi di seluruh organisasi dan mencakup praktik manajemen, seperti: (1) hening sejenak sebelum rapat; (2) sebuah ruang untuk keheningan, kelompok 
pendukung spiritual; (3) pemimpin spiritual untuk bimbingan dan dukungan spiritual batin yang rahasia; (4) memberikan staf dengan peluang pelatihan dan bimbingan dari pengembangan dan pembentukan teknis dan kepemimpinan hingga pernyataan visi pribadi; (5) mendukung konteks percakapan antara pekerja tentang kebutuhan yang sehat, pemenuhan pribadi, dan aspirasi spiritual; dan (6) perpustakaan yang meminjamkan materi spiritual dan agama (Fry \& Egel, 2017).

\section{Budaya Sekolah}

Istilah budaya sekolah umumnya mengacu pada kepercayaan, persepsi, hubungan, sikap, dan aturan tertulis dan tidak tertulis yang membentuk dan mempengaruhi setiap aspek tentang bagaimana sekolah berfungsi. Namun istilah budaya sekolah juga mencakup masalah yang lebih konkret, seperti keamanan fisik dan emosional siswa, keteraturan ruang kelas dan ruang publik, atau sejauh mana sekolah merangkul dan merayakan keragaman ras, etnis, bahasa, atau budaya. Seperti budaya sosial yang lebih besar, budaya sekolah dihasilkan dari perspektif, nilai, interaksi, dan praktik yang disadari maupun tidak sadar, dan sangat dibentuk oleh sejarah kelembagaan khusus sekolah (Stoll, 2018; Glossary of Education Reform, 2013). Siswa, orang tua, guru, administrator, dan anggota staf lainnya semuanya berkontribusi pada budaya sekolah mereka, seperti halnya pengaruh lain seperti komunitas di mana sekolah itu berada, kebijakan yang mengatur bagaimana operasinya, atau prinsip-prinsip di mana sekolah itu berada/didirikan.

Secara umum, budaya sekolah dapat dibagi menjadi dua bentuk dasar: budaya positif dan budaya negatif. Sejumlah peneliti, pendidik, dan penulis telah berusaha untuk mendefinisikan fitur utama dari budaya sekolah positif dan negatif, dan banyak penelitian, artikel, dan buku tersedia pada topik tersebut. Selain itu, banyak organisasi pendidikan, seperti National School Climate Center (2016), telah menghasilkan deskripsi rinci tentang budaya sekolah yang positif dan mengembangkan strategi untuk memperbaikinya. Budaya sekolah telah menjadi konsep sentral dalam banyak upaya untuk mengubah cara sekolah beroperasi dan meningkatkan hasil pendidikan. Sementara budaya sekolah sangat dipengaruhi oleh sejarah kelembagaannya, budaya juga membentuk pola sosial, kebiasaan, dan dinamika yang memengaruhi perilaku masa depan, yang dapat menjadi penghambat reformasi dan peningkatan.

Misalnya, jika budaya sekolah pada umumnya disfungsional, yaitu, jika ketegangan dan ketidakpercayaan antarpribadi adalah hal yang biasa, masalah jarang terjadi atau diselesaikan, atau anggota staf cenderung berdebat lebih banyak daripada mereka berkolaborasi atau terlibat dalam diskusi profesional yang produktif - kemungkinan ini faktor budaya akan secara signifikan mempersulit atau menghalangi upaya apa pun untuk mengubah cara sekolah beroperasi. Contoh sederhana ini menggambarkan mengapa budaya sekolah telah menjadi objek dari begitu banyak penelitian dan upaya reformasi - tanpa budaya sekolah yang kondusif untuk perbaikan, reformasi menjadi lebih sulit secara eksponensial. Budaya sekolah adalah salah satu konsep paling kompleks dan penting dalam pendidikan. Schein (1985) menganggap esensi dasar dari budaya organisasi adalah tingkat yang lebih dalam dari asumsi dasar dan kepercayaan yang dimiliki oleh anggota organisasi, yang beroperasi secara tidak sadar, dan yang mendefinisikan dalam dasar "menerima begitu saja" pandangan organisasi tentang dirinya dan lingkungannya.

Inilah jantung budaya sekolah dan apa yang membuatnya begitu sulit untuk dipahami dan diubah. Budaya menggambarkan bagaimana segala sesuatu berada dan bertindak sebagai layar atau lensa yang melaluinya dunia dilihat. Pada dasarnya ia mendefinisikan realitas bagi mereka yang berada dalam organisasi sosial, memberi mereka dukungan dan identitas dan menciptakan kerangka kerja untuk pembelajaran kerja. Setiap sekolah memiliki realitas atau pola pikir yang berbeda tentang kehidupan sekolah, sering ditangkap dalam ungkapan sederhana: cara sekolah melakukan sesuatu di sekitar sini (Deal \& Kennedy, 1983). Setiap sekolah juga memiliki pola pikirnya sendiri sehubungan dengan apa yang terjadi di lingkungan eksternalnya. Budaya, dengan demikian, unik secara situasional (Beare, dkk., 1989). Budaya sekolah dibentuk oleh sejarahnya, konteksnya, dan orang-orang di dalamnya. Sekolah sebagai bagian dari budaya masyarakat memiliki keunikan tersendiri jika dibandingkan dengan pranata sosial lain yang ada di masyarakat secara umum. Budaya sekolah adalah mengutamakan nilai-nilai pendidikan, moral, budi, perilaku baik, dan kemanusiaan. 


\section{Etika Profesi}

Dalam dunia globalisasi dan dunia kompetitif ini, mudah sekali menyaksikan beragam perubahan dalam sistem pendidikan. Karena, perubahan tidak terhindarkan, tujuan dan sasaran pendidikan berubah sesuai dengan kebutuhan, minat, dan persyaratan peserta didik, masyarakat suatu bangsa secara keseluruhan. Sekarang, konsep guru dan pengajaran juga berubah dari hari ke hari. Seorang guru di era kontemporer ini memiliki banyak tugas dan tanggung jawab untuk dimainkan. Selain memiliki kualifikasi akademik dan profesional yang baik, mereka juga harus memiliki pengetahuan etika profesi. Etika profesional seperti panduan, yang memfasilitasi guru untuk memberikan pendidikan yang berkualitas dan menanamkan nilai-nilai yang baik di antara peserta didik (Sherpa, 2018; Sultoni, dkk., 2019). Etika profesional akan menerangi guru bahwa mereka memiliki peran besar dalam membawa perubahan yang diinginkan dalam perilaku siswa. Ini juga membantu para guru untuk memahami profesi mereka sebagai guru.

Peran mereka bukan hanya untuk menjadi yang tertinggi dan otoriter di depan siswa dan kolega mereka. Tetapi kemudian mereka memiliki peran yang lebih luas dan bermakna untuk dimainkan. Guru yang memiliki etika profesi akan memperlakukan siswa mereka dengan cinta, perhatian, kasih sayang, dan komitmen. Selain itu, mereka akan selalu memastikan untuk memberikan kontribusi spesifik dari sudut pandang mereka. Oleh karena itu, makalah ini secara khusus menyoroti pentingnya etika profesional dalam guru. Penting mengajarkan etika profesional dalam program pendidikan guru. Kode etik formal memberikan dasar untuk pengambilan keputusan etis, tetapi mereka juga dapat membuat calon guru tidak diperlengkapi dengan baik untuk menghadapi kompleksitas situasi masalah yang unik (Soltis, 1986). Guru harus meningkatkan perilaku guru pra-jabatan ke berbagai realitas moral dunia kerja. Begitu sensitivitas atau kesadaran seperti itu terjadi, para guru kemudian perlu mengembangkan strategi dan keterampilan untuk mendiagnosis masalah etika dan membuat penilaian etis yang sehat.

Mengikuti gagasan tanggung jawab sipil semua orang dewasa untuk generasi baru, Seghedin (2014) telah mencoba, dalam berbagai penelitiannya, menunjukkan bahwa pengajaran melibatkan banyak prinsip dan nilai moral. Seghedin (2014) menyajikan bagian dari penelitiannya tentang etika pengajaran di bawah gagasan menjadi dimensi stabil profesionalisme pengajaran. Panggilan, pelibatan kerja, otonomi, tanggung jawab diungkapkan sebagai komponen utama dari profesionalitas moral pribadi (personal moral professionality); topik-topik ini terkait dan dibahas dalam perspektif keberadaan kepribadian profesional dari setiap guru. Studi Seghedin (2014) menunjukkan bahwa universitas dan sekolah seperti organisasi pembelajaran dan profesional dapat mempromosikan etos guru dan berkontribusi pada pengembangan etika terapan pengajaran dan, pada akhirnya, profesionalitas moral pribadi yang aktif.

Etika profesi guru tercemin pada kode etik guru. Kode etik guru dirancang untuk melindungi guru dan hak siswa. Penting bagi guru untuk memahami bahwa ketika mereka mendapatkan posisi mengajar, mereka setuju untuk mengikuti kode etik. Para guru diharapkan bersikap adil kepada semua siswa mereka dan tidak memanfaatkan posisi mereka dengan cara apa pun. Misalnya, guru tidak dapat menerima hadiah mahal dari siswa, karena itu mungkin membuat guru bias. Guru tidak dapat memaksakan kepercayaan pribadi pada siswa, karena mereka adalah pendengar yang menawan. Guru harus memiliki hubungan profesional dengan semua siswa dan tidak membiarkannya menjadi terlalu kasual dan akrab. Guru perlu melindungi keselamatan siswa dan tidak percaya bahwa ini adalah pekerjaan orang lain. Hal utama adalah jangan menyalahgunakan kekuatan yang mungkin diberikan posisi guru, kepada siswa. Guru perlu memikirkan implikasi apa yang terjadi.

\section{Kinerja Mengajar Guru}

Penilaian guru adalah mekanisme untuk meningkatkan pengajaran dan pembelajaran. Kompetensi profesional dan hati nurani guru adalah kunci pemberian pendidikan berkualitas di sekolah. Dalam sistem penilaian staf yang dirancang dengan baik, instrumen dan prosedur dapat merupakan pengembangan profesional yang berharga bagi guru dan memungkinkan manajemen sekolah untuk menilai kinerja guru. Sistem penilaian guru membantu dalam mengenali dan mendorong kinerja yang baik, mengidentifikasi bidang untuk pengembangan, dan meningkatkan kinerja guru secara keseluruhan (Education Bureau, 2013; Prastiawan, dkk., 2019). Guru diminta untuk mengidentifikasi semua alasan untuk evaluasi kinerja 
terakhir mereka. Pilihannya adalah evaluasi yang dijadwalkan secara berkala, untuk masa jabatan, untuk promosi, untuk upah yang pantas, atau karena guru memintanya, dan guru dapat memilih lebih dari satu alasan.

National Center for Education Statistics (2017) berdasarkan penelitiannya menyimpulkan: 97\% guru menyatakan bahwa evaluasi kinerja guru terbaru mereka adalah evaluasi yang dijadwalkan secara berkala; $9 \%$ menyatakan evaluasi mereka dilakukan sebagai bagian dari proses penganugerahan tenurial; $6 \%$ melaporkan bahwa evaluasi mereka akan menentukan penghargaan upah jasa; dan kurang dari $1 \%$ guru menyatakan evaluasi dilakukan atas permintaan guru. Tidak mengherankan, guru dengan status percobaan atau sementara lebih mungkin dibandingkan guru yang memegang sertifikat standar atau lanjutan untuk melaporkan bahwa evaluasi terakhir mereka dilakukan dengan tujuan menerima masa kerja. Hal yang sama berlaku untuk guru dengan 4 tahun atau kurang dalam pelayanan di sekolah saat ini dibandingkan dengan guru yang mengajar di sekolah selama 5 hingga 10 tahun atau 11 tahun atau lebih.

Penilaian kinerja mengajar guru dapat mengacu pada penilaian kemampuan dasar mengajar guru. Variasi dalam arti evaluasi formal harus selalu diingat ketika menafsirkan jumlah evaluasi yang telah diterima seorang guru. Definisi evaluasi formal yang dimasukkan dalam kuesioner menginstruksikan responden untuk menjawab sehubungan dengan proses evaluasi kinerja total dan sistematis dalam periode waktu tertentu (National Center for Education Statistics, 2017; Sumarsono, dkk., 2019; Ferguson \& Womack, 1993; Putri, dkk., 2019). Proses ini dapat berlangsung selama satu semester atau satu tahun, atau periode yang lebih lama, dan mungkin mencakup beberapa prosedur berbeda untuk mengevaluasi berbagai aspek kinerja pengajaran. Kemungkinan akan ada semacam penutupan dalam bentuk umpan balik kepada guru atau laporan tertulis dari hasilnya.

Namun, karena periode waktu yang termasuk dalam evaluasi formal mungkin bervariasi dan karena ada pertanyaan spesifik tentang apakah umpan balik diterima atau tidak oleh guru, serta jenis umpan balik yang diterima, poin-poin itu bukan bagian dari definisi yang ditawari. Menilai dari jumlah guru berapa kali mereka telah dievaluasi secara formal, beberapa mungkin melihat proses evaluasi formal dalam cara yang lebih terfragmentasi. Misalnya, setiap kejadian pengamatan kelas tampaknya telah dihitung sebagai evaluasi formal oleh beberapa responden, meskipun mereka semua mungkin telah menjadi bagian dari proses selama satu tahun. Di sisi lain, beberapa guru yang diwawancarai menjelaskan bahwa pada awal karir mengajar mereka, mereka menerima evaluasi formal beberapa kali setahun, dan ketika mereka memperoleh pengalaman, mereka secara resmi dievaluasi setiap tahun atau dua tahun sekali (National Center for Education Statistics, 2017).

\section{Pengaruh Kepemimpinan Pembelajaran, Kepemimpinan Perubahan, Kepemimpinan Spiritual, Budaya Sekolah, dan Etika Profesi terhadap Kinerja Mengajar Guru}

Penelitian ini menyimpulkan ada pengaruh yang signifikan kepemimpinan pembelajaran, kepemimpinan perubahan, kepemimpinan spiritual, budaya sekolah, dan etika profesi terhadap kinerja mengajar guru. Penelitian ini selaras dengan penelitian Bafadal, dkk., (2018b) yang menyimpulkan ada pengaruh yang signifikan variabel kepemimpinan pembelajaran, kepemimpinan perubahan, dan kepemimpinan spiritual terhadap kinerja mengajar guru. Kepemimpinan pembelajaran yang diterapkan kepala sekolah dapat mempengaruhi secara signifikan kinerja guru dalam mengajar (Al-Mahdy, dkk., 2017; Mustafa, dkk., 2015). Taylor, dkk., (2011) menyatakan bahwa kepala sekolah yang profesional dan menerapkan kepemimpinan perubahan mempengaruhi secara signifikan kinerja mengajar guru. Wills (2016) berdasarkan hasil penelitiannya menyimpulkan kepemimpinan perubahan memiliki pengaruh secara langsung terhadap kinerja sekolah dan kinerja mengajar guru. Polat (2011) menyatakan kepemimpinan spiritual memiliki pengaruh yang signifikan terhadap kinerja bahawan. Kepemimpinan spiritual mempengaruhi penilaian bawahan terhadap gaya kepemimpinan dan dapat meningkatkan kinerja bawahan (Yi-Chen \& Li, 2013; Gunawan, dkk., 2017a; Gunawan, dkk., 2017b).

Olivier (2001) mengembangkan kerangka kerja konseptual, yakni Model Komunitas Pembelajaran Profesional, dikembangkan untuk mengatur dan membuat konsep hubungan antara budaya sekolah, efikasi diri guru, efikasi kolektif, kepedulian manusia, niat untuk tinggal, dan efektivitas organisasi. Langkah-langkah awal dikembangkan untuk menilai efikasi diri guru dan efikasi kolektif dan revisi / 
modifikasi tindakan digunakan untuk budaya sekolah, kepedulian manusia, dan niat untuk tetap tinggal. Mengikuti perkembangan sosial dan ekonomi yang pesat di kawasan Asia-Pasifik dalam beberapa dekade terakhir, ada minat yang semakin besar terhadap perbedaan budaya dalam pendidikan antara Timur dan Barat (Cheong, 2000). Minat ini meluas ke kekuatan budaya yang membentuk fitur proses sekolah dan mendominasi efektivitas pendidikan dalam hal prestasi akademik siswa. Sayangnya, banyak penelitian dan perdebatan baru-baru ini tentang budaya menderita dari sejumlah kelemahan metodologis dan konseptual utama, termasuk kebingungan dalam konsepsi, penggunaan istilah budaya yang sewenang-wenang, pengaitan yang berlebihan dengan efek budaya, dan ketidaktahuan tingkat analisis. Beberapa penelitian tampaknya mampu memperdalam pemahaman tentang faktor budaya atau lintas budaya dalam efektivitas pendidikan.

Merupakan masalah untuk menerapkan tipe etika ini ke dalam praktik profesional yang terletak karena deontologi cenderung mengurangi etika ke moralitas populer atau bahkan ke moralisme anakronistik (Kostogriz, 2009). Secara tradisional, ketika profesional menggantungkan sirapnya dan menyatakan dirinya siap untuk menerima klien, ia mengaku atau mengakui kompetensi teknis berdasarkan tradisi pembelajaran (May, 1980); dan, lebih lanjut, ia menyatakan dirinya bertanggung jawab secara moral untuk keahlian ini, dan siap dalam beberapa hal untuk menempatkannya untuk melayani kebutuhan manusia. Profesional, tentu saja, menerima bayaran untuk karyanya, tetapi mungkin dia tidak, dengan cara menggunakan pengetahuannya terutama untuk mendapatkan kekuatan pribadi, atau untuk menunjukkan keahlian. Ia bergabung dengan pengetahuan dan kompetensi dengan substansi moral, kekuatan pengetahuan dengan beberapa ukuran filantropi. Guru yang terampil perlu memiliki karakteristik etika yang mengagumkan dalam dimensi individu dan sosialnya (Heidari, dkk., 2015). Guru harus berusaha untuk mendidik jiwanya sendiri sebelum melakukan upaya dalam mendidik orang lain mempertimbangkan beberapa poin penting. Lebih baik baginya untuk memiliki kehati-hatian dalam semua urusannya. Guru seharusnya tidak mencoba mendidik siapa pun sebelum berkenalan dengan sifatnya. Guru juga harus murah hati dan setia kepada yang lain. Akhirnya, diharapkan dari guru semacam itu untuk mendapatkan tingkat keterampilan yang sangat tinggi dalam menasihati dan membimbing siswa.

Kisah-kisah tentang apa yang disebut krisis dalam profesionalisme dalam pengajaran dan pendidikan guru dalam beberapa tahun terakhir telah membalikkan pengikisan epistemologis pengetahuan profesional dan masalah-masalah seputar sintesis teori dan praktik yang menopang kinerja guru (Humphreys \& Hyland, 2002; Sobri, dkk., 2019). Dikatakan bahwa konsentrasi pada kinerja dalam pengajaran dan pengembangan profesional harus disambut, asalkan kinerja guru tidak didefinisikan dalam istilah teknis atau instrumental. Menanggapi kecenderungan menuju kebijakan dan praktik yang berdasarkan bukti dan efektifitas pendidikan berbasis hasil mekanistik dalam debat pendidikan kontemporer, Humphreys \& Hyland (2002) menyimpulkan pada tradisi mengajar sebagai seni dan menggunakan argumen yang diambil dari musik dan wawasan yang diperoleh dari metafora - bahwa profesionalisme guru dapat ditingkatkan melalui perhatian pada spontanitas pengajaran yang intuitif, improvisasi, dan eksistensialis sebagai kinerja artistik.

\section{SIMPULAN}

Berdasarkan hasil analisis data dapat disimpulkan: (1) implementasi kepemimpinan pembelajaran, kepemimpinan perubahan, kepemimpinan spiritual, budaya sekolah, etika profesi, dan kinerja mengajar guru Sekolah Menengah Pertama (SMP) berbasis pesantren di Jawa Timur termasuk dalam kategori baik; dan (2) ada pengaruh yang signifikan kepemimpinan pembelajaran, kepemimpinan perubahan, kepemimpinan spiritual, budaya sekolah, dan etika profesi terhadap kinerja mengajar guru Sekolah Menengah Pertama (SMP) berbasis pesantren di Jawa Timur. Kinerja mengajar guru merupakan variabel yang mempengaruhi keefektifan belajar dan prestasi siswa. Oleh sebab itu, perlu didukung secara optimal dari berbagai variabel yang secara teknis dapat dilaksanakan oleh kepala sekolah, seperti kepemimpinan, komitmen, lingkungan, budaya, dan pengembangan profesional guru. 


\section{DAFTAR RUJUKAN}

Al-Mahdy, Y. F. H., Emam, M. M., \& Hallinger, P. 2017. Assessing the Contribution of Principal Instructional Leadership and Collective Teacher Efficacy to Teacher Commitment in Oman. Teaching and Teacher Education, 69, 191-201.

Argadinata, H., \& Gunawan, I. (2019). The Leadership of Pancasila in Education: Foundation for Strengthening Student Characters in the Industrial Revolution Era 4.0. The 4th International Conference on Education and Management (COEMA 2019). Atlantis Press.

Bafadal, I., Juharyanto, Nurabadi, A., \& Gunawan, I. (2018a). Pengaruh Kepemimpinan Pembelajaran, Kepemimpinan Perubahan, dan Kepemimpinan Spiritual yang Diterapkan di Sekolah terhadap Kualitas Kinerja dan Hasil Belajar (Output) pada Sekolah Dasar di Malang Raya. Laporan penelitian tidak diterbitkan. Malang: LP2M Universitas Negeri Malang.

Bafadal, I., Nurabadi, A., \& Gunawan, I. (2018b). The Influence of Instructional Leadership, Change Leadership, and Spiritual Leadership Applied at Schools to Teachers' Performance Quality. International Conference on Education and Technology (ICET 2018). Atlantis Press.

Bafadal, I., Sobri, A. Y., \& Nurabadi, A. (2016). Kepemimpinan Pembelajaran dalam Implementasi Kurikulum di Sekolah Unggul. Laporan penelitian tidak diterbitkan. Malang: Fakultas Ilmu Pendidikan Universitas Negeri Malang.

Bafadal, I., Sobri, A. Y., Nurabadi, A., \& Gunawan, I. (2019). Standards of Competency of Head of School Beginners as Leaders in Learning Innovation. 5th International Conference on Education and Technology (ICET 2019). Atlantis Press.

Beare, H., Coldwell, B. J., \& Millikan, R. H. (1989). Creating an Excellent School: Some New Management Techniques. London: Routhedge.

Bradham, J. (2017). The Five Principles of Change Leadership. Chicago: The Giving Institute.

Bruns, B., Costa, L., \& Cunha, N. (2018). Through the Looking Glass: Can Classroom Observation and Coaching Improve Teacher Performance in Brazil? Economics of Education Review, 64, 214-250.

Cheong, C. Y. (2000). Cultural Factors in Educational Effectiveness: A framework for Comparative Research. School Leadership \& Management, 20(2), 207-225.

Creswell, J. W. (2009). Research Design: Qualitative, Quantitative, and Mixed Methods Approaches. Thousand Oaks, CA: Sage.

Daresh, J. C., \& Playco, M. A. (1995). The Arrival of the New Principal: Reactions of Staff. Theory into Practice, 23, 168-173.

Deal, T. E., \& Kennedy, A. A. 1983. Culture: A New Look Through Old Lenses. The Journal of Applied Behavioral Science, 19(4), 498-505.

Education Bureau. 2013. Teacher Performance Management, (Online), (https://www.edb.gov.hk/attachment/en/ sch-admin/sbm/sbm-forms-references/staff-appraisal-system/TPMguide.pdf), diakses 2 Desember 2019.

Eggen, P., \& Kauchak, D. (2014). Educational Psychology: Windows on Classrooms. New York: Pearson Prentice Hall, Upper Saddle River.

Ferguson, P., \& T. Womack, S. (1993). The Impact of Subject Matter and on Teaching Performance. Journal of Teacher Education, 44(1), 55-63.

Fry, L. W. (2003). Toward a Theory of Spiritual Leadership. The Leadership Quarterly, 14(6), 693-727.

Fry, L. W. J., \& Egel, E. (2017). Spiritual Leadership: Embedding Sustainability in the Triple Bottom Line. Graziadio Business Review, 20(3), 1-19.

Fry, L. W., Vitucci, S., \& Cedillo, M. (2005). Spiritual Leadership and Army Transformation: Theory, Measurement, and Establishing A Baseline. The Leadership Quarterly, 16(5), 835-862.

Fry, L., \& Kriger, M. (2009). Toward a Theory of Being-Centered Leadership: Multiple Levels of being as Context for Effective Leadership. Human Relations, 62(11), 1667-1696.

Giacalone, R., \& Jurkiewicz, C. (2003). Toward a Science of Workplace Spirituality. Dalam Giacalone, R., \& Jurkiewicz, C. (Eds.), Handbook of Workplace Spirituality and Organizational Performance. New York: M. E. Sharp.

Glossary of Education Reform. (2013). School Culture, (Online), (https://www.edglossary.org/school-culture/), diakses 2 Desember 2019.

Greenstone, A. F. (2018). Ethics and Public Integrity in Space Exploration. Acta Astronautica, 143, 322-326.

Gunawan, I. (2014). Metode Penelitian Kualitatif: Teori dan Praktik. Jakarta: PT Bumi Aksara. 
Gunawan, I. (2017). Pengantar Statistika Inferensial. Jakarta: Rajawali Pers.

Gunawan, I. (2019). Develop Educational Leadership by Applying Values and Ethics to Strengthen Student Character. 5th International Conference on Education and Technology (ICET 2019). Atlantis Press.

Gunawan, I., Benty, D. D. N., Kusumaningrum, D. E., Sumarsono, R. B., Sari, D. N., Pratiwi, F. D., ... \& Hui, L. K. (2019a). Validitas dan Reliabilitas Angket Keterampilan Manajerial Mahasiswa. JAMP: Jurnal Administrasi dan Manajemen Pendidikan, 2(4), 247-257.

Gunawan, I., Kusumaningrum, D. E., \& Sumarsono, R. B. (2019b). Investigation of Principal Leadership Based on Pesantren: Descriptive Study about Implementation of Human Resources Empowerment Models Based on Soft System Methodology. The 4th International Conference on Education and Management (COEMA 2019). Atlantis Press.

Gunawan, I., Suminah, Murdiyah, S., Andriningrum, H., \& Onenda, G. (2018a). Improving Student Learning Achievement through Behavior Modification Approach. 1st International Conference on Early Childhood and Primary Education (ECPE 2018). Atlantis Press.

Gunawan, I., Suminah, S., Murdiyah, S., Andriningrum, H., \& Onenda, G. (2018b). Improving Student Learning Achievement through Behavior Modification Approach. 1st International Conference on Early Childhood and Primary Education (ECPE 2018). Atlantis Press.

Gunawan, I., Ulfatin, N., Sultoni, S., Sunandar, A., Kusumaningrum, D. E., \& Triwiyanto, T. (2017a). Pendampingan Penerapan Strategi Pembelajaran Inovatif dalam Implementasi Kurikulum 2013. Abdimas Pedagogi: Jurnal Ilmiah Pengabdian kepada Masyarakat, 1(1), 37-47.

Gunawan, I., Ulfatin, N., Sultoni, S., Sunandar, A., Kusumaningrum, D. E., \& Triwiyanto, T. (2017b). Pendampingan Penerapan Strategi Pembelajaran Inovatif dalam Implementasi Kurikulum 2013 di MIS Lowokwaru Kota Malang. Laporan pengabdian kepada masyarakat tidak diterbitkan. Malang: Fakultas Ilmu Pendidikan Universitas Negeri Malang.

Hallinger, P., \& Murphy, J. (1985). Assessing the Instructional Management Behavior of Principals. The Elementary School Journal, 86(2), 217-247.

Heidari, M. H., Heshi, K. N., Mottagi, Z., Amini, M., \& Shiri, A. S. (2015). Teachers' Professional Ethics from Avicenna's Perspective. Educational Research and Reviews, 10(17), 2460-2468.

Hollins, E. R. (2008). Culture in School Learning: Revealing the Deep Meaning. New York: Routledge.

Humphreys, M., \& Hyland, T. 2002. Theory, Practice and Performance in Teaching: Professionalism, Intuition, and Jazz. Educational Studies, 28(1), 5-15.

Jenkins, B. (2009). What It Takes To Be an Instructional. Principal, 34-37. (Online), (https://www.naesp.org/sites/ default/files/J-F_p34.pdf), diakses 2 Mei 2018.

Kalmanovich-Cohen, H., Pearsall, M. J., \& Christian, J. S. (2018). The Effects of Leadership Change on Team Escalation of Commitment. The Leadership Quarterly, 29(2), 365-371.

Katkat, D. 2014. The Leadership Abilities of the Teachers. Procedia - Social and Behavioral Sciences, 116, 38803885.

Kostogriz, A. (2009). Professional Ethics in Multicultural Classrooms: English, Hospitality and the Other. Dalam Miller, J., Kostogriz, A., \& Gearon, M., (Eds.)., Culturally and Linguistically Diverse Classrooms: New Dilemmas for Teachers. Toronto: Multilingual Matters.

Kusumaningrum, D. D. E., Ulfatin, N. N., Maisyaroh, M., Triwiyanto, T. T., \& Gunawan, I. (2017a). Community Participation in Improving Educational Quality. 2nd International Conference on Educational Management and Administration (CoEMA 2017). Atlantis Press.

Kusumaningrum, D. E., Gunawan, I., Sumarsono, R. B., \& Triwiyanto, T. (2018a). Panduan Pengelolaan Perpustakaan Sekolah Dasar. Malang: Universitas Negeri Malang, UM Press.

Kusumaningrum, D. E., Sumarsono, B. R., \& Gunawan, I. (2017b). Pengembangan Model Pemberdayaan Sumber Daya Manusia Sekolah Menengah Pertama Berbasis Pesantren dengan Pendekatan Soft System Methodology. Laporan Penelitian Tahun I tidak diterbitkan. Malang: LP2M Universitas Negeri Malang.

Kusumaningrum, D. E., Sumarsono, B. R., \& Gunawan, I. (2018b). Pengembangan Model Pemberdayaan Sumber Daya Manusia Sekolah Menengah Pertama Berbasis Pesantren dengan Pendekatan Soft System Methodology. Laporan Penelitian Tahun II tidak diterbitkan. Malang: LP2M Universitas Negeri Malang.

Kusumaningrum, D. E., Sumarsono, B. R., \& Gunawan, I. (2019). Pengembangan Model Pemberdayaan Sumber Daya Manusia Sekolah Menengah Pertama Berbasis Pesantren dengan Pendekatan Soft System Methodology. Laporan Penelitian Tahun III tidak diterbitkan. Malang: LP2M Universitas Negeri Malang.

Lares, A. (2019). What Is Change Leadership? (Online), (https://shapironegotiations.com/what-is-change- 
leadership/), diakses 2 Desember 2019.

Leavitt, H. J. (2016). Managerial Psychology. Chicago: University of Chicago Press.

Lynch, M. (2015). Important Concepts of Instructional Leadership, (Online), (https://www.theedadvocate.org/ important-concepts-of-instructional-leadership/), diakses 2 Desember 2019.

May W.F. (1980) Professional Ethics: Setting, Terrain, and Teacher. Dalam Callahan, D., \& Bok, S. (Eds), Ethics Teaching in Higher Education: The Hastings Center Series in Ethics. Boston: Springer.

Mustafa, N., Radzi, M., Hazlina., Rohana, W. A., \& Nawawi, M. 2015. Principals' Instructional Leadership and Teachers' Commitment in Three Mara Junior Science Colleges (MJSC) in Pahang, Malaysia. Procedia Social and Behavioral Sciences, 191, 1848-1853.

National Center for Education Statistics. (2017). Public Elementary Teachers' Views on Teacher Performance Evaluations, (Online), (https://nces.ed.gov/surveys/frss/publications/94097/index.asp?sectionid=2), diakses 2 Desember 2019.

National School Climate Center. (2016). School Climate Resource Center (SCRC) Launches! National School Climate Center, 10(2), 1-8.

Nurabadi, A., Gunawan, I., \& Sari, Y. L. (2019a). The Application of Informal Supervision to Improve the Quality of Learning in Laboratory Schools. The 4th International Conference on Education and Management (COEMA 2019). Atlantis Press.

Nurabadi, A., Sucipto, S., \& Gunawan, I. (2019b). Informal Supervision Model "Managing by Walking About" in Improving Quality of Learning. 5th International Conference on Education and Technology (ICET 2019). Atlantis Press.

Olivier, D. F. (2001). Teacher Personal and School Culture Characteristics in Effective Schools: Toward a Model of a Professional Learning Community. Disertasi tidak diterbitkan. Louisiana: Louisiana State University.

Pambudi, B. A., \& Gunawan, I. (2019). Instructional Leadership as an Effort to Increase Teacher Professionalism in the Industrial Revolution Era 4.0. The 4th International Conference on Education and Management (COEMA 2019). Atlantis Press.

Patterson, J. L. (1993). Leadership for Tomorrow's Schools. Alexandria: Association for Supervision and Curriculum Development.

Polat, S. (2011). The Level of Faculty Members'Spiritual Leadership (SL) Qualities Display According to Students in Faculty of Education. Procedia - Social and Behavioral Sciences, 15, 2033-2041.

Prastiawan, A., Gunawan, I., Putra, A. P., Surahman, E., Dewantoro, D. A., ... \& Nuraini, N. L. S. (2019). Office Management of Educational Institutions: Theories and Applications. 5th International Conference on Education and Technology (ICET 2019). Atlantis Press.

Putri, A. F., Andriningrum, H., Rofiah, S. K., \& Gunawan, I. (2019). Teacher Function in Class: A Literature Review. 5th International Conference on Education and Technology (ICET 2019). Atlantis Press.

Robbins, S. P., \& Coulter, M. A. (2015). Management. New York: Pearson.

Saputra, B. R., Adha, M. A., Ariyanti, N. S., \& Gunawan, I. (2019). Tips for Principal in Managing One Roof School (SATAP) in Underdeveloped Area. The 4th International Conference on Education and Management (COEMA 2019). Atlantis Press.

Schein, E. H. (1985). Organizational Culture and Leadership. San Francisco: Jossey-Bass Publishers.

Seghedin, E. (2014). From the Teachers Professional Ethics to the Personal Professional Responsibility. Acta Didactica Napocensia, 7(4), 13-22.

Sherpa, K. (2018). Importance of Professional Ethics for Teachers. International Education and Research Journal, 4(3), 16-18.

Sobri, A. Y., Bafadal, I., Nurabadi, A., \& Gunawan, I. (2019). Validity and Reliability of Questionnaire Problematics Leadership Beginner School Principals. The 4th International Conference on Education and Management (COEMA 2019). Atlantis Press.

Soltis, J. F. (1986). Teaching Professional Ethics. Journal of Teacher Education, 37(3), 2-4.

Stoll, L. (2018). School Culture: Black Hole or Fertile Garden for School Improvement? Dalam Prosser, J., (Eds.), School Culture. New York: Sage.

Sultoni, Gunawan, I., \& Rosalinda, T. N. (2018a). Pengaruh Pembentukan Tim dan Kepemimpinan Spiritual terhadap Motivasi Diri Mahasiswa. JMSP: Jurnal Manajemen dan Supervisi Pendidikan, 2(3), 210-216.

Sultoni, Gunawan, I., \& Rosalinda, T. N. (2018b). Upaya Mahasiswa dalam Menyiapkan Diri Masuk ke Dunia Kerja: Suatu Kajian Deskriptif. Seminar Nasional Pendidikan, Tema: Mendidik Cerdas Generasi Digital, Fakultas Ilmu Pendidikan Universitas Negeri Malang, 1(1), 143-148. 
Sultoni, Gunawan, I., \& Sari, D. N. (2018c). Pengaruh Etika Profesional terhadap Pembentukan Karakter Mahasiswa. JAMP: Jurnal Adminitrasi dan Manajemen Pendidikan, 1(3), 279-283.

Sultoni, Gunawan, I., \& Sari, D. N. (2019). Validity and Reliability of Character Education Internalization Instruments. The 4th International Conference on Education and Management (COEMA 2019). Atlantis Press.

Sumarsono, R. B., Kusumaningrum, D. E., Gunawan, I., Alfarina, M., Romady, M., Ariyanti, N. S., \& Budiarti, E. M. (2019). Training on the Implementation of Cooperative Learning Models as an Effort to Improve Teacher's Performance. The 4th International Conference on Education and Management (COEMA 2019). Atlantis Press.

Taylor, M., Goeke, J., Klein, E., Onore, C., \& Geist, K. (2011). Changing Leadership: Teachers Lead the Way for Schools that Learn. Teaching and Teacher Education, 27(5), 920-929.

Whittington, J. L., Pitts, T. M., Kageler, W. V., \& Goodwin, V. L. (2005). Legacy leadership: The leadership wisdom of the Apostle Paul. The Leadership Quarterly, 16(5), 749-770.

Wills, G. (2016). Principal Leadership Changes and their Consequences for School Performance in South Africa. International Journal of Educational Development, 51, 108-124.

Yi-Chen, C., \& Li, C. I. (2013). Assessing the Spiritual Leadership Effectiveness: The Contribution of Follower's Self-Concept and Preliminary Tests for Moderation of Culture and Managerial Position. The Leadership Quarterly, 24(1), 240-255. 